Polibotánica

ISSN electrónico: 2395-9525

POLIBETÁNICA polibotanica@gmail.com Instituto Politécnico Nacional México http:www.polibotanica.mx

\title{
DISPERSAL AND GERMINATION OF SEEDS INGESTED BY CARNIVORES IN THE ZAPOTITLAN DE LAS SALINAS VALLEY, MEXICO
}

\section{DISPERSIÓN Y GERMINACIÓN DE SEMILLAS INGERIDAS POR CARNÍVOROS EN EL VALLE DE ZAPOTITLÁN DE LAS SALINAS, MEXICO}

Zarco-Mendoza, P.; L. Ríos-Casanova, y H. Godínez-Álvarez

DISPERSAL AND GERMINATION OF SEEDS INGESTED BY CARNIVORES IN THE ZAPOTITLAN DE LAS SALINAS VALLEY, MEXICO

DISPERSIÓN Y GERMINACIÓN DE SEMILLAS INGERIDAS POR CARNÍVOROS EN EL VALLE DE ZAPOTITLÁN DE LAS SALINAS, MEXICO

POLIBETÁNICA

Instituto Politécnico Nacional
Núm. 46: 139-147 México. Julio 2018

DOI: $10.18387 /$ polibotanica.46.7 


\section{DISPERSAL AND GERMINATION OF SEEDS INGESTED BY CARNIVORES IN THE ZAPOTITLAN DE LAS SALINAS VALLEY, MEXICO}

\section{DISPERSIÓN Y GERMINACIÓN DE SEMILLAS INGERIDAS POR CARNÍVOROS EN EL VALLE DE ZAPOTITLÁN DE LAS SALINAS, MEXICO}

Zarco-Mendoza, P.;

L. Ríos-Casanova, y

H. Godínez-Álvarez

DISPERSAL AND

GERMINATION OF SEEDS INGESTED BY

CARNIVORES IN THE

ZAPOTITLAN DE LAS

SALINAS VALLEY, MEXICO

DISPERSIÓN Y

GERMINACIÓN DE

SEMILLAS INGERIDAS POR

CARNÍVOROS EN EL

VALLE DE ZAPOTITLÁN

DE LAS SALINAS, MEXICO

\section{POLIBETÁNICA}

Instituto Politécnico Nacional

Núm. 46: 139-147. Julio 2018

DOI:

10.18387/polibotanica.46.7

\author{
P. Zarco-Mendoza \\ L. Ríos-Casanova \\ H. Godínez-Álvarez/hgodinez@unam.mx \\ Unidad de Biotecnología y Prototipos, Facultad de Estudios Superiores Iztacala, \\ Universidad Nacional Autónoma de México. \\ Av. de los Barrios 1, Los Reyes Iztacala, Tlalnepantla 54090, \\ Estado de México, México.
}

ABSTRACT: Seed dispersal by animals influences plant recruitment depending on the number of dispersed seeds, the treatment given to seeds in the gut, and the probability of seed germination and seedling survival in the sites where seeds are defecated in the field. Seed dispersal by carnivores influences plant recruitment in temperate and tropical ecosystems. However, data on seed dispersal by carnivores in tropical drylands is limited. In these ecosystems, plants produce large numbers of fruits that may be eaten by carnivores, yet we ignore whether seed dispersal potentially influences plant recruitment. Hence, we evaluated the number of seeds dispersed by carnivores, the germination proportion after gut passage, and the types of sites where carnivores defecated seeds in the Zapotitlan de las Salinas Valley. We collected 384 scats to quantify the number of seeds per scat, the percentage of damaged seeds per scat, and the number of scats per site. We also compared the germination proportion between seeds removed from fruits and scats in laboratory experiments. We found seeds from 18 plant species. The scats had $133.1 \pm 262.8$ seeds from $1.4 \pm 0.6$ plant species, and 3 $\pm 12 \%$ of damaged seeds. The scats were dropped more frequently than expected in rocky areas and less frequently than expected in open and canopy areas. The gut passage had positive effects on germination in two species, neutral effects in six species, and negative effects in four species. These results suggest that seed dispersal by carnivores can potentially influence the recruitment of several plant species in the Zapotitlan de las Salinas Valley.

Key words: endozoochory, México, plant recruitment, mammals, Tehuacán-Cuicatlán Valley.

RESUMEN: La dispersión de las semillas por animales influye en el reclutamiento de las plantas dependiendo del número de semillas dispersadas, el tratamiento de las semillas en el intestino y la probabilidad de germinación y supervivencia de las plántulas en los sitios en donde las semillas son defecadas en el campo. La dispersión de semillas por carnívoros influye en el reclutamiento de las plantas en los ecosistemas templados y tropicales. Sin embargo, los datos sobre la dispersión de semillas por carnívoros en las regiones tropicales secas son limitados. En estos ecosistemas, las plantas producen un alto número de frutos que pueden ser comidos por los carnívoros, no obstante, ignoramos si la dispersión de las semillas influye potencialmente en el reclutamiento de las plantas. Por lo tanto, evaluamos el número de semillas dispersado por los carnívoros, la proporción de germinación de las semillas defecadas y los tipos de sitios en donde los carnívoros defecan las semillas en el Valle de Zapotitlán de las Salinas. Colectamos 384 excretas para cuantificar el número de semillas por excreta, el 
porcentaje de semillas dañadas por excreta y el número de excretas por sitio. También comparamos la proporción de germinación de las semillas de los frutos y las semillas de las excretas en experimentos de laboratorio. Encontramos semillas de 18 especies de plantas. Las excretas tuvieron $133.1 \pm 262.8$ semillas de $1.4 \pm 0.6$ especies de plantas y $3 \pm 12 \%$ de semillas dañadas. Las excretas fueron encontradas más frecuentemente en áreas rocosas y menos frecuentemente en áreas abiertas y áreas bajo arbustos. El paso por el intestino tuvo efectos positivos en la germinación de dos especies, efectos neutros en seis especies y efectos negativos en cuatro especies. Estos resultados sugieren que la dispersión de semillas por carnívoros puede influir potencialmente en el reclutamiento de varias especies de plantas en el Valle de Zapotitlán de las Salinas.

Palabras clave: Endozoocoria, México, reclutamiento de plantas, mamíferos, Valle de Tehuacán-Cuicatlán.

\section{INTRODUCTION}

Seed dispersal by animals influences plant recruitment, thus modifying plant population structure (Jordano, 1992). The influence on plant recruitment depends on the number of seeds dispersed by animals, the treatment given to seeds in the gut, and the probability of germination and seedling survival in the sites where seeds are defecated in the field (Schupp, Jordano, \& Gómez, 2010). Animals may disperse large numbers of seeds, without damaging them during gut passage, but defecating seeds in unsuitable sites for germination and seedling survival. Hence, to elucidate the influence of seed dispersal on plant recruitment, we need to investigate the number of seeds dispersed by animals, the germination of seeds after gut passage, and the types of sites where animals defecate seeds in the field.

Seed dispersal by carnivores influences the recruitment of several plant species in Mediterranean shrublands (Herrera, 1989; Willson, 1993), temperate drylands (Silverstein, 2005), temperate deciduous forests (Koike, Morimoto, Goto, Kozakai, \& Yamazaki, 2008), and tropical forests (Chakravarthy \& Ratnam, 2015; Zhou, Zhang, Kaneko, Newman, \& Wang, 2008). In these ecosystems, carnivores eat large numbers of fruits without damaging seeds during their passage through the digestive tract. Seeds dispersed by carnivores also show high germination capacity and seedling survival (Traveset \& Verdú, 2002), although some seeds are unable to establish themselves in the sites where they are defecated in the field (Bustamante, Simonetti, \& Mella, 1992; Chávez-Ramírez \& Slack, 1993). This evidence indicates that seed dispersal by carnivores potentially modifies the population structure of some plant species in these ecosystems. However, data on seed dispersal by carnivores in other ecosystems such as tropical drylands is still limited (Godínez-Alvarez, Rojas-Martínez, \& Zarco-Mendoza, 2007). Tropical drylands in North America have high numbers of plant and carnivore species, which may establish fruit-frugivore interactions. However, we ignore whether seed dispersal by carnivores potentially influences plant recruitment in this ecosystem.

The Zapotitlan de las Salinas Valley is a Mexican tropical dryland with 184 plant species and 11 carnivore species (Osorio, Valiente-Banuet, Dávila, \& Medina, 1996; Ramírez-Pulido, González-Ruiz, \& Genoways, 2005). Among plants, cacti and legumes produce large numbers of fruits that may be dispersed by carnivores. Columnar cacti, for example, can produce $>800$ $\mathrm{kg}$ of fleshy fruits in one year (Godínez-Alvarez et al., 2007). However, very few studies have evaluated the dispersal of seeds by carnivores. Three studies have evaluated germination after seeds passed through the digestive tract in Myrtillocactus geometrizans (Pérez-Villafaña \& Valiente-Banuet, 2009), Neobuxbaumia tetetzo (Godínez-Alvarez, Valiente-Banuet, \& RojasMartínez, 2002), and Stenocereus pruinosus (García, 2000). Yet, data on other basic aspects such as the plant species eaten by carnivores, the quantity of seeds from each plant species that are dispersed by these animals, and the types of sites where seeds are defecated in the field such as those in open areas or beneath perennial plants is still limited. Hence, our goal was to evaluate the number of seeds dispersed by carnivores, the proportion of seeds germinated after 
gut passage, and the types of sites where carnivores defecate seeds. Carnivore species were considered a guild of seed dispersers (i.e., a group of species that use one resource in a similar way, independently of their taxonomic identity) as a first approximation to evaluate their influence on plant recruitment. To accomplish our goal, we collected carnivore scats to quantify the number of species and seeds per scat, the percentage of damaged seeds per scat, and the number of scats in different types of sites. We also compared the proportion of germination between seeds removed from fruits and scats through laboratory experiments.

\section{MATERIAL AND METHODS}

The study was conducted in the Zapotitlán de las Salinas Valley $\left(18^{\circ} 20^{\prime} \mathrm{N}, 97^{\circ} 28^{\prime} \mathrm{W}, 1550 \mathrm{~m}\right.$ a.s.l.) within the Tehuacán-CuicatlánValley in Puebla, south-central Mexico. The mean annual rainfall is $400 \mathrm{~mm}(80 \%$ of which falls during June to September) and the mean annual temperature is $21^{\circ} \mathrm{C}$ (Dávila et al., 2002). The main soil types are litosols, calcic cambisols, and calcic xerosols (López-Galindo et al., 2003). The plant communities vary depending on landscape position. Thus, xeric shrubland mixed with different columnar cactus species occurs on the mountain slopes, tropical dry forest at the top of the valley, and mesquite shrubland dominated by Prosopis laevigata at the bottom of the valley (Osorio et al., 1996).

We collected ripe fruits and fresh scats (i.e., soft scats with a dark color and strong odor) in four characteristic plant communities of the region: (1) xeric shrubland mixed with the columnar cactus N. tetetzo, (2) xeric shrubland mixed with the columnar cactus Cephalocereus columnatrajani, (3) tropical dry forest, and (4) mesquite shrubland. The fruits and scats were monthly collected along trails during one year, to obtain a comprehensive list of fruits eaten by carnivores. The fruits were identified to species level, placed in paper bags, and transported to the laboratory where seeds were extracted to form a reference collection. The scats were placed in paper bags and transported to the laboratory where they were dried at room temperature and broken up to remove seeds. The seeds were identified to species level using our reference collection and classified as intact or damaged (i.e., broken or cracked seeds). We calculated the mean number of species, the mean number of seeds, and the mean percentage of damaged seeds per scat. The sites where scats were collected in the field were registered as rocky areas, open areas, and canopy areas. The number of scats in each site was compared using a chi-square test.

The effect of gut passage on seed germination was examined in the laboratory by comparing seeds taken from fruits and scats. The seeds were disinfected with a $30 \%$ bleach solution for 5 min and then rinsed with tap water. Depending on the availability of ingested seeds per species, 3-5 Petri dishes containing moistened filter paper were set up to contain 8-25 seeds of each seed type (i.e., seeds from fruits and scats). The dishes were placed in an environmental chamber $\left(25-30^{\circ} \mathrm{C}, 24 \mathrm{~h}\right.$ fluorescent light) where they were checked daily to record the number of germinated seeds (i.e., seeds with emerged cotyledons). The experiments lasted 10-30 days, depending on the time required to reach maximum germination for each species. The proportion of germinated seeds from fruits and scats of each species were arcsine transformed to meet the assumptions of normality and the equality of variances. Because data met these assumptions, the proportions were compared with Student's $t$-tests for independent samples using JMP, version 8.0.

\section{RESUlts}

We found 18 plant species in 384 carnivore scats (table 1). Ziziphus amole was the most frequent species (43\%, i.e., 164 out of a total of 384 scats) followed by nine species (e.g., Prosopis laevigata, Myrtillocactus geometrizans, and Castela tortuosa) with frequencies ranging between 1-20\%. Eight species (e.g., Opuntia pilifera, Vallesia glabra, and Bumelia laetevirens) had frequencies lower than $1 \%$. Seven out of the 18 plant species belonged to the family Cactaceae, whereas the remaining eleven species belonged to a different plant family each. 
Table 1. Plant species found in carnivore scats. The number of scats collected in the field was 384 and the number of seeds found in scats was 51099. $-=$ Data not available.

\begin{tabular}{|c|c|c|c|}
\hline Family / Plant species & No. of seeds & No. of scats (\%) & $\begin{array}{l}\text { No. of seeds / scat } \\
\quad(\text { mean } \pm 1 \text { SD })\end{array}$ \\
\hline \multicolumn{4}{|l|}{ Anacardiaceae } \\
\hline Schinus molle & 3300 & $49(13)$ & $67 \pm 58$ \\
\hline \multicolumn{4}{|l|}{ Apocinaceae } \\
\hline Vallesia glabra & 34 & $3(0.8)$ & $11 \pm 9$ \\
\hline \multicolumn{4}{|l|}{ Burseraceae } \\
\hline Bursera sp. & 15 & $1(0.3)$ & - \\
\hline \multicolumn{4}{|l|}{ Cactaceae } \\
\hline Echinocactus platyacanthus & 2 & $1(0.3)$ & - \\
\hline Mammillaria carnea & 7442 & $4(1)$ & $1861 \pm 1166$ \\
\hline Myrtillocactus geometrizans & 10087 & $62(16)$ & $163 \pm 166$ \\
\hline Neobuxbaumia tetetzo & 106 & $1(0.3)$ & - \\
\hline Opuntia pilifera & 139 & $3(0.8)$ & $46 \pm 42$ \\
\hline Stenocereus pruinosus & 62 & $2(0.8)$ & $31 \pm 35$ \\
\hline Stenocereus stellatus & 177 & $1(0.3)$ & - \\
\hline \multicolumn{4}{|l|}{ Fabaceae } \\
\hline Prosopis laevigata & 2007 & $78(20)$ & $26 \pm 24$ \\
\hline \multicolumn{4}{|l|}{ Loranthaceae } \\
\hline Phoradendron californicum & 6407 & $31(8)$ & $207 \pm 111$ \\
\hline \multicolumn{4}{|l|}{ Opiliaceae } \\
\hline Agonandra conzattii & 169 & $12(3)$ & $14 \pm 7$ \\
\hline \multicolumn{4}{|l|}{ Rhamnaceae } \\
\hline Ziziphus amole & 2346 & $164(43)$ & $14 \pm 13$ \\
\hline \multicolumn{4}{|l|}{ Rubiaceae } \\
\hline Chiococca sp. & 7538 & $45(12)$ & $168 \pm 150$ \\
\hline \multicolumn{4}{|l|}{ Sapotaceae } \\
\hline Bumelia laetevirens & 26 & $2(0.8)$ & $13 \pm 1$ \\
\hline \multicolumn{4}{|l|}{ Simaroubaceae } \\
\hline Castela tortuosa & 1214 & $52(14)$ & $23 \pm 21$ \\
\hline \multicolumn{4}{|l|}{ Verbenaceae } \\
\hline Lantana camara & 10028 & $34(9)$ & $295 \pm 241$ \\
\hline
\end{tabular}

The scats had $1.4 \pm 0.6$ plant species (mean $\pm 1 \mathrm{SD}, \mathrm{N}=384$, range 1-4) and $133.1 \pm 262.8$ seeds $(\mathrm{N}=384$, range 1-3561). The percentage of damaged seeds per scat was $3 \pm 12(\mathrm{~N}=384$, range $0-96 \%)$. The number of scats differed between sites $\left(\chi^{2}=99.4\right.$, d. f. $\left.=2, p<0.001\right)$. The scats were found more frequently than expected in rocky areas $(76 \%)$, but less frequently than expected in canopy areas (13\%) and open areas (11\%).

Gut passage had contrasting effects on germination depending on the plant species (table 2). The seeds from scats showed higher germination than seeds from fruits in Myrtillocactus geometrizans and Vallesia glabra. Germination did not differ between both types of seeds in Agonandra conzattii, Castela tortuosa, Chiococca sp., Lantana camara, Mammillaria carnea, and Prosopis laevigata. The seeds from scats showed lower germination than seeds from fruits in Neobuxbaumia tetetzo, Opuntia pilifera, Stenocereus pruinosus, and S. stellatus. Some species such as Ziziphus amole and Phoradendron californicum did not germinate in any of the treatments. Bumelia laetivirens, Bursera sp., Echinocactus platyacanthus, and Schinus molle could not be examined due to the insufficient number of these seeds. 
Table 2. Proportion of germination of seeds extracted from fruits and scats. Data are mean \pm 1 standard error. The species name in bold indicate significant differences in germination between fruits and scats. d. f. = degrees of freedom.

\begin{tabular}{lccccc}
\hline \multicolumn{1}{c}{ Plant species } & Fruits & Scats & Student's t-test & d. f. & P value \\
\hline Agonandra conzattii & $0.45 \pm 0.09$ & $0.46 \pm 0.13$ & 0.02 & 6 & 0.99 \\
Castela tortuosa & $0.26 \pm 0.07$ & $0.16 \pm 0.12$ & 1.40 & 8 & 0.19 \\
Chiococca sp. & $0.04 \pm 0.02$ & $0.05 \pm 0.02$ & 0.53 & 6 & 0.61 \\
Lantana camara & $0.43 \pm 0.07$ & $0.36 \pm 0.03$ & 0.88 & 6 & 0.41 \\
Mammillaria carnea & $0.64 \pm 0.06$ & $0.73 \pm 0.05$ & 1.15 & 6 & 0.29 \\
Myrtillocactus geometrizans & $\mathbf{0 . 2 7} \pm \mathbf{0 . 0 9}$ & $\mathbf{0 . 5 5} \pm \mathbf{0 . 0 3}$ & $\mathbf{3 . 0 7}$ & $\mathbf{6}$ & $\mathbf{0 . 0 2}$ \\
Neobuxbaumia tetetzo & $\mathbf{1 . 0 0} \pm \mathbf{0 . 0}$ & $\mathbf{0 . 8 7} \pm \mathbf{0 . 0 1}$ & $\mathbf{2 5 . 4 9}$ & $\mathbf{6}$ & $\mathbf{0 . 0 0}$ \\
Opuntia pilifera & $\mathbf{0 . 7 8} \pm \mathbf{0 . 0 8}$ & $\mathbf{0 . 5 2} \pm \mathbf{0 . 0 5}$ & $\mathbf{2 . 5 9}$ & $\mathbf{6}$ & $\mathbf{0 . 0 4}$ \\
Prosopis laevigata & $0.08 \pm 0.06$ & $0.24 \pm 0.11$ & 1.35 & 8 & 0.21 \\
Stenocereus pruinosus & $\mathbf{1 . 0 0} \pm \mathbf{0 . 0}$ & $\mathbf{0 . 8 5} \pm \mathbf{0 . 0 4}$ & $\mathbf{7 . 7 5}$ & $\mathbf{4}$ & $\mathbf{0 . 0 2}$ \\
Stenocereus stellatus & $\mathbf{0 . 5 1} \pm \mathbf{0 . 0 6}$ & $\mathbf{0 . 2 2} \pm \mathbf{0 . 0 9}$ & $\mathbf{2 . 4 5}$ & $\mathbf{6}$ & $\mathbf{0 . 0 5}$ \\
Vallesia glabra & $\mathbf{0 . 5 3} \pm \mathbf{0 . 1 9}$ & $\mathbf{1 . 0 0} \pm \mathbf{0 . 0}$ & $\mathbf{3 . 5 3}$ & $\mathbf{4}$ & $\mathbf{0 . 0 2}$ \\
\hline
\end{tabular}

\section{DISCUSSION}

The results showed that carnivore scats have relatively large numbers of intact seeds. Gut passage has contrasting effects on seed germination, and most seeds are defecated in rocky areas. These results suggest that seed dispersal by carnivores may potentially influence the recruitment of several plant species in the Zapotitlan de las Salinas Valley. However, carnivore species were considered as a guild of seed dispersers; thus, further studies should evaluate the species-specific effect of carnivores on plant recruitment in this region. Furthermore, scats were only collected for one year and seed germination was only evaluated in laboratory conditions. Hence, further studies should evaluate temporal variation in the number of seeds dispersed by carnivores and seedling survival in the field.

The scats had an average of 133 seeds from one plant species and 3\% of damaged seeds. These results are similar to those reported for carnivore scats in the Mediterranean shrublands, where they had 140 seeds from only one plant species and $0.9 \%$ of damaged seeds (Herrera, 1989; Matías, Zamora, Mendoza, \& Hódar, 2010). The large number of intact seeds found in scats suggests that carnivores can disperse seeds away from parent plants. However, the dispersal of large numbers of seeds can also negatively affect plant recruitment because it increases seed predation risk and intraspecific competition among seedlings (Bustamante et al., 1992; ChávezRamírez \& Slack, 1993; Herrera, 1989; Schupp et al., 2010).

The dispersal of seeds away from parent plants by carnivores may increase the probability of plant recruitment in the Zapotitlan de las Salinas Valley. However, seeds should remain viable after passage through the digestive tract and should be defecated in sites suitable for germination and seedling survival. Our results showed that gut passage had positive, neutral, and negative effects on germination depending on plant species. Furthermore, most seeds were defecated in rocky areas compared to open and canopy areas. These findings indicate that carnivores differently influence plant recruitment. Thus, M. geometrizans and V. glabra increased their germination after passing through the digestive tract of carnivores. This effect is similar to that reported for other plant species in Mediterranean shrublands and tropical 
drylands (Bustamante et al., 1992; Pérez-Villafaña \& Valiente-Banuet, 2009; Traba, Arrieta, Herranz, \& Clamagirand, 2006), in which seed ingestion by carnivores also enhances their germination. However, the seeds defecated in rocky areas may have low probabilities of germination and seedling survival. This is particularly significant for M. geometrizans because this species only establishes in sites beneath perennial nurse plants (Pérez-Villafaña \& ValienteBanuet, 2009). Other species such as A. conzattii, P. laevigata, C. tortuosa, Chiococca sp., $L$. camara, and $M$. carnea neither increase, nor decrease their germination after passing through the digestive tract of carnivores. Different studies have reported that gut passage did not alter the germination of seeds in several plant species (Cypher \& Cypher, 1999; Wilson \& Thomas, 1999). Despite the neutral effects of gut passage on germination, carnivores may benefit these species by dispersing their seeds to sites away from parent plants. For example, the seeds dispersed to rocky areas may increase the recruitment of $P$. laevigata because this species can establish in the harsh conditions of these sites (Sánchez de la Vega \& Godínez-Alvarez, 2010). The species Neobuxbaumia tetetzo, O. pilifera, S. pruinosus, and S. stellatus decreased their germination after passing through the digestive tract of carnivores. These results are similar to those reported for other plant species, in which seeds defecated by carnivores had lower germination than seeds taken from fruits (Cypher \& Cypher, 1999; Godínez-Alvarez et al., 2002; Silverstein, 2005). This negative effect suggests that carnivores damage seeds during mastication and/or digestion. Thus, further studies should evaluate the condition of the seed coat after gut passage to determine whether carnivores are damaging seed embryos. Lastly, $Z$. amolle, $P$. californicum, B. laetivirens, and $S$. molle did not germinate after passing through the digestive tract of carnivores because their seeds were probably dormant. However, carnivores may benefit these plant species by dispersing their seeds to sites away from parent plants where seeds may enter the soil seed bank (Matías et al., 2010).

\section{CONCLUSIONS}

Carnivore scats have relatively large numbers of intact seeds. The gut passage has positive or neutral effects on germination of eight plant species, although it has negative effects in four species. Most seeds are defecated in rocky areas. These results suggest that seed dispersal by carnivores can potentially influence the recruitment of several plant species in the Zapotitlán de las Salinas Valley.

\section{ACKNOWLEDGMENTS}

We would like to thank Jesús Ortega Esquinca and Tanya Ortega Zarco for their help during fieldwork. We would also like to thank Lorena Miranda Carbajal for reviewing the manuscript. This study was financially supported by the Programa de Apoyo a Proyectos de Investigación e Innovación Tecnológica (PAPIIT), Universidad Nacional Autónoma de México (UNAM), through grant IN213402.

\section{LITERATURA CITADA}

Bustamante, R. O., Simonetti, J. A., \& Mella, J. E. (1992). Are foxes legitimate and efficient seed dispersers? A field test. Acta Oecologica, 13, 203-208.

Chakravarthy, D., \& Ratnam, J. (2015). Seed dispersal of Vitex glabrata and Prunus ceylanica by Civets ( Viverridae ) in Pakke Tiger Reserve, north-east India : spatial patterns and post-dispersal seed fates. Tropical Conservation Science, 8, 491-504. https://doi.org/10.1177/194008291500800213

Chávez-Ramírez, F., \& Slack, R. D. (1993). Carnivore fruit-use and seed dispersal of two selected plant species of the Edwards Plateau, Texas. The Southwestern Naturalist, 38, 141-145. https://doi.org/10.2307/3672066 
Cypher, B.-L., \& Cypher, E. A. (1999). Germination rates of tree seeds Ingested by coyotes and raccoons. The American Midland Naturalist, 142, 71-76. https://doi.org/10.1674/00030031(1999)142[0071:GROTSI]2.0.CO;2

Dávila, P., Arizmendi, M. C., Valiente-Banuet, A., Villaseñor, J. L., Casas, A., \& Lira, R. (2002). Biological diversity in the Tehuacán-Cuicatlán Valley, Mexico. Biodiversity and Conservation, 11, 421-442. https://doi.org/10.1023/A:1014888822920

García, V. O. (2000). Dispersión biótica de semillas de la cactácea columnar Stenocereus pruinosus (Otto) F. Buxb., en el Valle de Tehuacán, Puebla, México. Universidad Nacional Autónoma de México.

Godínez-Alvarez, H., Rojas-Martínez, A., \& Zarco-Mendoza, P. (2007). Dispersión de semillas por mamíferos: el caso del Valle de Tehuacán, una zona árida del centro de México. In G. Sánchez-Rojas \& A. Rojas-Martínez (Eds.), Tópicos en sistemática, biogeografía, ecología y conservación de mamíferos (pp. 135-149). México: Universidad Autónoma del Estado de Hidalgo.

Godínez-Alvarez, H., Valiente-Banuet, A., \& Rojas-Martínez, A. (2002). The role of seed dispersers in the population dynamics of the columnar cactus Neobuxbaumia tetetzo. Ecology, 83, 2617-2629. https://doi.org/10.2307/3071819

Herrera, C. M. (1989). Frugivory and seed dispersal by carnivorous mammals, and associated fruit characteristics, in undisturbed Mediterranean habitats. Oikos, 55, 250-262. https://doi.org/10.2307/3565429

Jordano, P. (1992). Fruits and frugivory. In M. Fenner (Ed.), Seeds. The ecology of regeneration in plant communities (pp. 105-156). Wallingford: CAB International.

Koike, S., Morimoto, H., Goto, Y., Kozakai, C., \& Yamazaki, K. (2008). Frugivory of carnivores and seed dispersal of fleshy fruits in cool-temperate deciduous forests. Journal of Forest Research, 13, 215-222. https://doi.org/10.1007/s10310-008-0069-5

López-Galindo, F., Muñoz-Iniestra, D., Hernández-Moreno, M., Soler-Aburto, A., CastilloLópez, M. C., \& Hernández-Arzate, I. (2003). Análisis integral de la toposecuencia y su influencia en la distribución de la vegetación y la degradación del suelo en la subcuenca de Zapotitlán Salinas, Puebla. Boletín de La Sociedad Geológica Mexicana, 56, 19-41.

Matías, L., Zamora, R., Mendoza, I., \& Hódar, J. A. (2010). Seed dispersal patterns by large frugivorous mammals in a degraded mosaic landscape. Restoration Ecology, 18, 619627. https://doi.org/10.1111/j.1526-100X.2008.00475.x

Osorio, B. O., Valiente-Banuet, A., Dávila, P., \& Medina, R. (1996). Tipos de vegetación y diversidad $B$ en el Valle de Zapotitlán de las Salinas, Puebla, México. Boletín de La Sociedad Botánica de México, 59, 35-58.

Pérez-Villafaña, M. G., \& Valiente-Banuet, A. (2009). Effectiveness of dispersal of an ornithocorous cactus Myrtillocactus geometrizans (Cactaceae) in a patchy environment. The Open Biology JournalOpen Biology Journal, 2, 101-113. Retrieved from internal-pdf://243.167.50.137/2009_Perez-Villafana_Effectivenessof dispersa.pdf

Ramírez-Pulido, J., González-Ruiz, N., \& Genoways, H. H. (2005). Carnivores from the Mexican state of Puebla: distribution, taxonomy, and conservation. Mastozoología Neotropical, 12, 37-52. Retrieved from http://www.doaj.org/abstract?id=155666

Sánchez de la Vega, G., \& Godínez-Alvarez, H. (2010). Effect of gut passage and dung on seed germination and seedling growth: donkeys and a multipurpose mesquite from a Mexican inter-tropical desert. Journal of Arid Environments, 74, 521-524. https://doi.org/10.1016/j.jaridenv.2009.09.020

Schupp, E. W., Jordano, P., \& Gómez, J. M. (2010). Seed dispersal effectiveness revisited: a conceptual review. New Phytologist, 188, 333-353. https://doi.org/10.1111/j.14698137.2010.03402.x

Silverstein, R. P. (2005). Germination of native and exotic plant seeds dispersed by coyotes (Canis latrans) in southern California. The Southwestern Naturalist, 50, 472-478. 
Recibido:

3/febrero/2017

Aceptado:

17/enero/2018
Traba, J., Arrieta, S., Herranz, J., \& Clamagirand, M. C. (2006). Red fox (Vulpes vulpes L.) favour seed dispersal, germination and seedling survival of Mediterranean Hackberry (Celtis australis L.). Acta Oecologica, 30, 39-45. https://doi.org/10.1016/j.actao. 2006.01.004

Traveset, A., \& Verdú, M. (2002). A meta-analysis of the effect of gut treatment on seed germination. In D. J. Levey, W. R. Silva, \& M. Galetti (Eds.), Seed dispersal and frugivory: ecology, evolution and conservation (pp. 339-350). Wallingford: CAB International.

Willson, M. F. (1993). Mammals as seed-dispersal mutualists in North America. Oikos, 67, 159-176. https://doi.org/10.2307/3545106

Wilson, J. A., \& Thomas, B. (1999). Diet and seed dispersal efficiency of the gray fox (Urocyon cinereoragenteus) in Chaparral. Bulletin of the Southern California Academy of Sciences, 98, 119-126.

Zhou, Y. B., Zhang, L., Kaneko, Y., Newman, C., \& Wang, X. M. (2008). Frugivory and seed dispersal by a small carnivore, the Chinese ferret-badger, Melogale moschata, in a fragmented subtropical forest of central China. Forest Ecology and Management, 255, 1595-1603. https://doi.org/10.1016/j.foreco.2007.11.018 